\title{
Measuring management and leadership competencies of business school educated managers in South Africa
}

\author{
Ahmed Shaikh \\ Regent Business School, Durban, South Africa \& NWU Potchefstroom Business School \\ Christo A Bisschoff \\ Christoff J Botha \\ NWU Potchefstroom Business School \\ North-West University, South Africa
}

\begin{abstract}
Keywords
Management, leadership, competencies, validity, measurement.
\end{abstract}

\begin{abstract}
This paper explores a model to measure managerial and leadership competence of business school educated managers. It starts by reviewing the literature on general management and leadership, seeking to establish a broad theoretical framework to guide this study. After statistically ensuring that the respective theoretical measuring criteria selected do measure the specific management and leadership competency, the paper then presents a model to measure management and leadership competencies. The final model has a total of eleven management and leadership competencies. These are Personal Value System, Career Awareness, Ethical and External Influences, Leading Change, Cultural Sensitivity, Team Building, Strategic Leadership, Conflict Management, Communication Skills, Global Leadership Mindset and Emotional Intelligence. This paper goes on to statistically measure the management and leadership competencies while also determining if the demographic variables influence the management and leadership competencies in any way. Also, the paper seeks to determine if any significant correlations exist between management and leadership competencies. The results of this study are of value to business school educated managers who aim to improve their managerial and leadership skills. It is also of value to researchers and scholars who intend to explore this avenue of managerial and leadership competency models further.
\end{abstract}

Corresponding author: Christo A Bisschoff

Email addresses for corresponding author: Christo.bisschoff@nwu.ac.za

First submission received: $8^{\text {th }}$ February 2018

Revised submission received: $25^{\text {th }}$ April 2018

Accepted: 22 ${ }^{\text {nd }}$ May 2018

\section{Introduction}

In the current highly integrated global economy where many organisations operate across multiple geographies, the importance of a talented and competent workforce is axiomatic. Competent employees are not only central to productive and enriched work environments but also contribute to prosperous outcomes for organisational performance. These, and other, business environmental issues have generated an urgency among organisations to build their executive teams with the requisite managerial and leadership competencies, so that these competencies can be deployed in a manner that achieves superior individual and organisational performance.

Previous studies in the field of work-based competencies demonstrate a link between managerial and leadership competencies, and superior executive performance. Following the formalisation of management and leadership competencies as a managerial concept, management and leadership competencies have gained significant impetus as a substantive management focus area in recent human resource management literature (Lewis, Donaldson-Feilder and Tharani, 2012; Sinh, 2016; Bagraim et al., 2016). The concept of competency-based human resources has been explored seminally by David McClelland (1973). Since then it has moved from a novel approach to widespread practice in the last four decades since McClelland first proposed it as a key differentiator of performance. According to research in this area by Analoui and Hosseini (2001) and later by Boyatzis and Ratti (2009), managerial effectiveness is 
strongly correlated to organisational effectiveness and economic performance. In this respect, Analoui and Hosseini (2001) argued that competent managers and leaders have played a significant role in the overall success of their organisations and development of their societies. In an earlier study, Boyatzis and Case (1989) found that management educated graduates, and more specifically MBA graduates, displayed a greater number of skills and competencies related to effective managerial performance. Later, as more studies were completed (Analoui and Hosseini, 2001; Mintzberg, 2004, 2005, 2008; Camuffo et al., 2009), patterns of managerial and leadership competencies could be observed that recurrently appeared to distinguish exceptional performers. This led to the development of numerous competency models; this avenue of research is even more relevant today where managers are confronted by the disruption of the Fourth Industrial Revolution (Cornellissen, 2017).

Most recently though, relentless change within and outside organisational boundaries, coupled with volatility and uncertainty in the general business environment, has forced managers and leaders to rethink organisational design and the managerial skills sets required to succeed under such circumstances. In this regard, Hoffmann (2016) warns that conventional organisational structures with multiple hierarchical levels will disappear in the context of the Fourth Industrial Revolution. In line with this view, Truxillo, Bauer and Erdogan (2016) confirm that the modern organisation has to develop and learn continuously and that the shifting organisational boundaries will lead to adjusted organisational structures. One key aspect, as highlighted by Sinh (2016:14), is that, in contrast to a conventional executive, effective contemporary leaders are characterised by their openness and willingness to embrace change and innovation. Thus, with the acceleration in innovation and massive disruptions in global business brought about by the digital economy, Cornellissen (2017) warns that managers and leaders must have the skills and competencies to identify managerial problems and know suitable strategies to fix them.

Given this background, the purpose of this study is to measure management and leadership competencies of business school educated managers in South Africa. The current study also attempts to determine if significant correlations exist between the demographic variables and management and leadership competencies as well as determine if significant correlations exist between the management and leadership competencies.

\section{Problem Statement}

The profile of the $21^{\text {st }}$ century workplace is undergoing large-scale and fundamental changes. Managers, therefore, have to operate in a complex environment and are required to respond rapidly to demands that are, at most times, unpredictable (Bagraim et al., 2016). In recent years though, there has been a rising surge of contemporary criticisms of management education as well as approaches to management and leadership development (Varela, Burke and Norbit, 2013). A number of these post-2000 studies assert inadequacies in the development of managerial skills and competencies (Mintzberg, 2004; Pfeffer and Fong, 2004). The seminal claim by one of the pioneering proponents holding this view, Mintzberg (2004:199) stated that "management education sits worlds apart from that of management development".

Despite the growing concerns about the impact of graduate management education, Boyatzis and Case (1989) argued that few studies have measured their impact on the development of students' managerial and leadership competencies. Here Camuffo et al. (2009) contend that even in instances where researchers support the hypothesis that management education leads to enhanced managerial performance, measurement of the specific skills and competencies associated with such management education remains somewhat hazy and unclear. This is especially true in the South African context where, apart from studies by Thekiso (2011) and Shaikh (2013), there is a dearth of such scientific and empirical research. This article, therefore, addresses this specific problem of measuring management and leadership competencies amongst business school educated managers in South Africa.

\section{Research Objectives}

The primary objective of this article is to measure management and leadership competencies of business school educated managers in South Africa. 
This primary objective is achieved by addressing the following secondary objectives:

Theoretically study management and leadership;

Ensure the relevancy of of the theoretically selected measuring criteria; and

Empirically measure the competencies and demographic profiles of the respondents.

\section{Theory on Management and Leadership}

To ground the theoretical framework of this study, literature is presented on the role of management and leadership in organisations, with brief discussions on the nature of management and the nature of leadership. Second, a brief debate on whether management and leadership are theoretically a different or interrelated concept is presented, explaining the various paradigms held by diverse researchers and scholars. Lastly, an attempt is made to reconcile the long-standing debate around whether effective management and leadership are all about nature or nurture.

\section{The role of management and leadership in organisations}

The challenges of being an effective manager have never been greater. In a globalised economy that is characterised by rapid advances in technology and hyper-competition, organisations have become highly complex and exposed to constant change. Smit, Botha and Vrba (2016) suggest that, in addition to dealing with issues such as climate change, sustainability, business ethics and corporate governance, present-day managers must also be sensitive to cultural differences that are central to doing business around the globe.

In the South African environment specifically, Smit et al. (2016) go on to argue that organisational managers are facing even greater challenges such as a politically turbulent environment characterised by corruption and bribery. Coupled with these challenges, a very tough labour market, a volatile public higher education sector and Black Economic Empowerment transformation charters for almost every sector of the South African economy, managers have to reflect on sound management principles to be effective in meeting organisational outcomes.

In response to the question: "Why does management matter?", Achadinha et al. (2015) offer a range of reasons which demonstrate that well-managed organisations are more competitive and effective in meeting consumers' needs, generating greater revenues, ensuring a skilled workforce and ultimately serving the needs of society. In support of this notion, Northouse (2013) points out that a manager's link to business performance is even more relevant at present times and that management is a key success factor in the modern business environment. Smit et al. (2016) put forward the view that while organisations have been part of human life for centuries, societies depend on business organisations now, more than ever before, to meet the changing needs of all its members. Competent managers are therefore required to help organisations achieve their mission and goals and be successful in building prosperous societies.

\section{The nature of management}

Organisations, especially business organisations, serve the needs of societies in a number of ways by transforming resources into goods and services that societies need. To achieve the organisations' mission and goals, however, capable managers are required to stimulate and guide the organisation to deploy its limited resources in productive and purposeful ways. Accordingly, in carrying out their tasks, managers still perform the four fundamental functions: planning, organising, leading and controlling (Smit et al., 2016).

\section{Managerial roles}

In general terms, management refers to getting things done through people. Management, however, is a generic term that is open to various interpretations (Mullins, 2010). Achadinha et al. (2016) more formally describe management as a "process of coordinating work activities through the functions of planning, organising, activating (leading) and controlling". Here, the notion of "coordinating work activities" is what Achadinha et al. (2016) use to distinguish a managerial position from a non-managerial one. Bagraim et al. (2016) however argue that managers can no longer adhere to the rational view of planning, organising, leading and controlling. Instead, reflecting the chaos that best describes the present circumstances in businesses globally, Bagraim et al. (2016) put forward a view that most managers are involved in a variety of "intense, brief and disconnected activities" that they are required to work on. In 
other words, managers are often required to perform multiple roles at any given time. Table 1 below sets out the multiple roles of modern-day managers:

Table 1: The multiple roles of managers

\begin{tabular}{|l|l|}
\hline Interpersonal roles & $\begin{array}{l}\text { Figurehead of the team, unit or organisation } \\
\text { Leader of team members } \\
\text { Liaison with lateral contacts inside and outside the team and organisation }\end{array}$ \\
\hline Informational roles & $\begin{array}{l}\text { Monitor, collector and assimilator of information } \\
\text { Disseminator of information } \\
\text { Spokesperson, keeping influential others informed }\end{array}$ \\
\hline Decision roles & $\begin{array}{l}\text { Entrepreneur, agent of change } \\
\text { Disturbance handler, restoring functionality and performance, problem solver } \\
\text { Resource allocator } \\
\text { Negotiator in interpersonal and group relationships }\end{array}$ \\
\hline
\end{tabular}

Source: Bagraim et al. (2016)

\section{Managing in the global environment}

Globalization, technological development and changing customer needs create an environment of continuous fluctuation, discontinuity and change; all of which challenges the abilities of managers to anticipate and proactively deal with change. Compounding these difficulties, in a country like South Africa which is characterised by substantial diversity, managers have the additional challenges of developing shared values, building capacity and creating a team-based organisation where diversity becomes a competitive advantage (Robbins and Judge, 2014). To manage diversity in the workplace, a manager must be able to identify the dimensions of diversity in the workplace. Achadinha et al. (2015) suggest that these are divided into primary dimensions of diversity (race, gender, ethnicity, age, culture and physical ability) and secondary dimensions of diversity (education, religion, income levels, parental status, marital status, differences in geographical locations and work experience). The challenges for a manager, therefore, are to synergise these dimensions of diverse work teams to ensure that all role-players within teams contribute toward shared objectives and organisational outcomes.

\section{Leadership}

Leadership can be regarded as the fundamental sphere of managerial functioning that is correlated to individual and organisational success, financial performance and overall success (Lussier and Achua, 2013). There are many different definitions of leadership, and a general review of the literature would provide a plethora of definitions, sometimes differing significantly according to different societal norms and cultures. A common definition offered by Achadinha et al. (2015) explains leadership as the process of influencing organisational members to such an extent that they willingly work towards the achievement of organisational goals and outcomes.

Leadership as a construct and leadership theories, however, have evolved significantly over time and as such produced varying approaches to its interpretation (Ayers, 2015). In this regard, Bagraim et al. (2016) put forward a view that the way in which present-day organisations respond to the new challenges of radical change and immense volatility is fundamentally tied to the values, attitudes, styles and responses of their leaders. De Wit (2017) presents a contemporary, if not radical view of the nature of leadership as senior management's desire for organisational chaos as a prerequisite for strategic renewal. This means the unfreezing of existing structures, processes, routines and beliefs, and opening employees up to new possibilities of doing business with creativity and innovation. Following through with this argument, De Wit (2017) suggests that leaders ought to release the "energy, creativity and entrepreneurial potential pent up in their organisations" and must, therefore, be willing to let go and allow "some chaos to exist".

\section{Difference between management and leadership paradigm}

It has long been argued that not all managers are necessarily leaders, and not all leaders can necessarily be considered as managers (Robbins and Judge, 2012). Accordingly, the difference between management and leadership is seen as an ambiguous, inherently complex and long-standing debate. Historically, management and leadership have been described as being comprehensively researched yet 
having a high level of ambiguity about their conceptual underpinnings (Burns, 1978; Grint, 2005) and even being grounded in different academic disciplines (Ghoshal, 2005; Gill, 2006).

This may be primarily due to the distinction of leadership being based on the basic premise of change in organisations (Brocklehurst, Grey and Sturdy, 2009), while management is about producing disciplined results. In their paper, however, Edwards et al. (2015), while acknowledging the issues of change, explore notions of power as a point of departure for further theoretical debate and research. They go on to develop a four-part conceptual framework that includes: managers "doing" leadership, managers "becoming" leaders, "being" leaders and managers, and leaders "doing" management (see Figure 1).

Figure 1: Perspectives on management and leadership

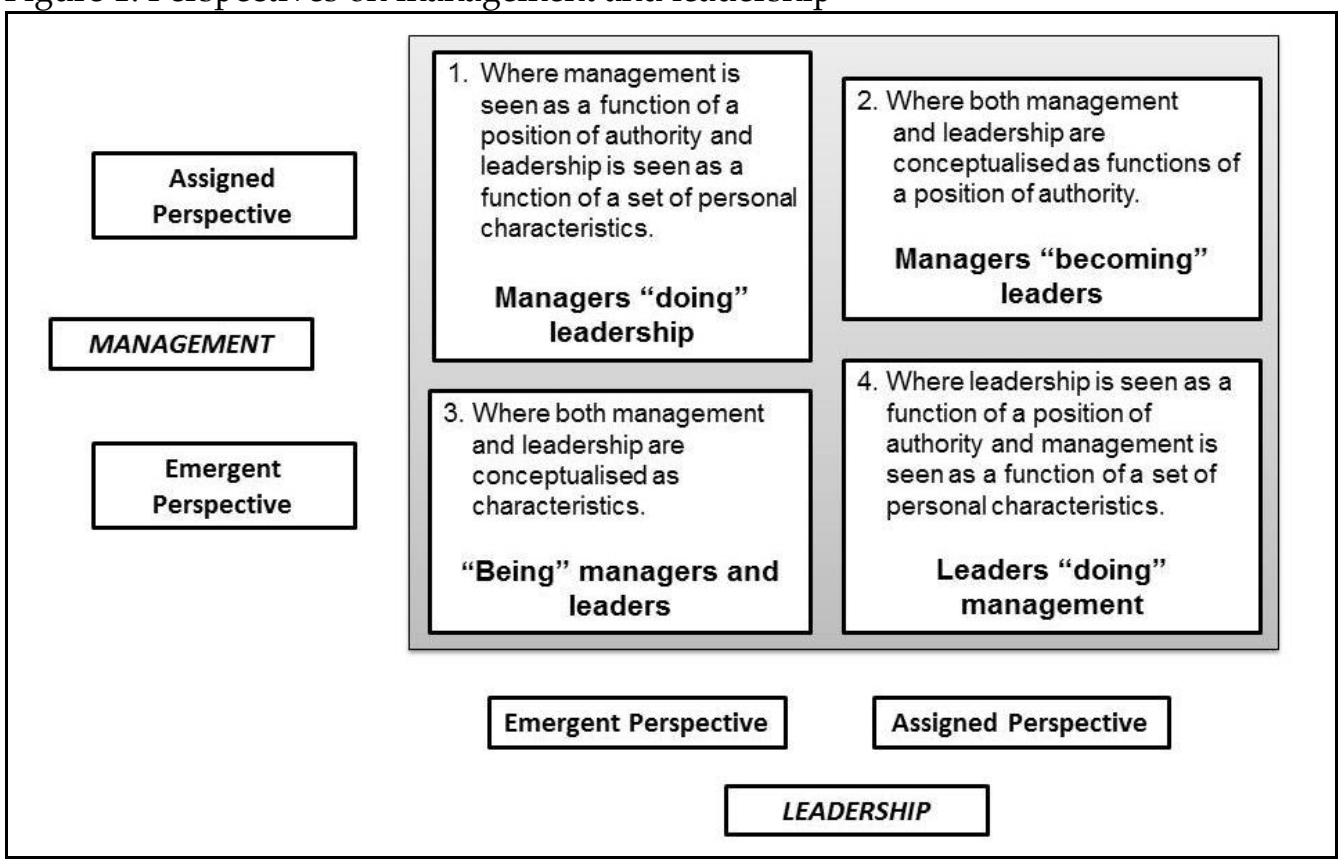

Source: Edwards et al. (2015)

Framing the differences between management and leadership within a paradox of control and chaos, the proposition of organisational chaos by De Wit (2017) as an essential prerequisite for strategic leadership can sound quite alarming for managers who seek to plan, organise, lead and control systematically. This view is useful in explaining that while managers seek order, control and disciplined implementation of plans, leaders seek to stimulate new ways of thinking about business by allowing experimentation and innovative initiatives. Leaders thereby accept a certain amount of disorder, expecting it to pay off regarding organisational success in the long run.

Taking a strategic management perspective, De Wit (2017) argues that while operational control gives managers influence over the activities within the current organisational system, strategic control gives leaders influence over changes to the organisational system itself.

\section{Interrelationships between management and leadership paradigm}

The conundrum as to whether management and leadership are interrelated or mutually exclusive is however still being debated in contemporary academic arguments (Walters, 2016; Aruda, 2016). The trajectory of this debate continues to move through the differences between management and leadership (Zaleznik, 1977) while Kotter (1990a) makes a case for the complementary nature of these two concepts. More recently though, Yukl and Lepsinger (2005) propose that leadership and management are interdependent and that their roles need to be integrated to achieve organisational effectiveness (Gleeson, 2016). In consonance with this view, Bedeian and Hunt (2006) put forward "the assumption that leadership is a subset of management, with both needing to be carried out to ensure organisational success". Mintzberg (2009) suggests that the manager has interpersonal roles and one of them is to be the leader. Further, some scholars use the terms management and leadership interchangeably (Walters, 2016) 
and argue that there is some degree of overlap between the two (Aruda, 2016). Others question the two concepts and admit the ongoing scholarly debate (Bolden, 2007; Buttigieg and West, 2013, Gleeson, 2016).

Kent (2005) suggests that while there may be a need to define the two concepts independently to ensure clarity in academic debate and research, he argues that the two processes are essentially integrative in nature. More recently, a seminal analysis of 80 studies on the topics of management and leadership by Nienaber (2010) who considered the similarities and differences claimed in these two concepts. Nienaber (2010) concluded that the literature demonstrates that "leadership and management are inextricably interwoven". Gleeson (2016) agrees that substantial overlapping exists and that both leaders and managers are performing inter-related tasks continuously while leading and managing teams.

This debate about the relationship between management and leadership highlights the ideological, ambiguous and problematic nature of the managing and leading those managers to consider themselves engaged in.

\section{Are management and leadership all about nature or nurture?}

This too is a long-standing debate that has been enduring since the management and leadership thinking originated. Although both management and leadership are strongly based in personal commitment (Biro, 2014), there are strong theoretical positions on the opposing views in management and leadership foundations regarding nature or nurture. The general consensus though possibly lies somewhere in the middle of this continuum - managers and leaders can be developed or nurtured, but they must also possess certain inherent characteristics to start with.

De Witt (2017) contends that not all managers have the requisite qualities to be effective leaders "either by nature or nurture". In answering the key question whether management and leadership competence is innate or acquired, some historical researchers highlight the importance of 'nature', claiming that managers require certain unique personality traits to be effective as leaders (Tucker, 1968; House and Aditya, 1997; Biro, 2014). Other researchers of that time placed greater emphasis on 'nurture', contending that effective leadership behaviour can be developed through deliberate training and effort (Kotter, 1990b; Nanus, 1992; Mintzberg, 2009). These researchers, resultantly, argued that a combination of genetics and environmental factors interact to produce effective leadership behaviour. In yet another emerging perspective on the nature versus nurture contention, some theorists are beginning to further nuance the debate by suggesting that, in addition to personal characteristics ('nature'), a significant part of leadership development derives from the exposure and challenges experienced on the job and only a small part comes from the 'nurture' element of formal training. Known as the 'developmental school', theorists in this school of thought hold the view that management and leadership are essentially grounded in experience and exposure (Kakabadse and Kakabadse, 1999; Alvesson and Svenningson, 2003; Ayers, 2015).

However, it seems that these two schools of thought continue up to today. Here Dissanayake (2016) states that: "Good managers, like leaders, are made; not born" while Anderson (2012) stands firm that leaders are born. Researchers at one of Ohio's leadership research centres, Edunote (2017), present even another scenario, namely that "Leaders are born, but managers are made".

Given the current competitive business environment, effective management and leadership are increasingly being regarded as the mainstay of organisational success. The strategy of developing such management and leadership is identifying candidates with certain innate personal characteristics (nature), focusing on their development through appropriate training and mentorship (nurture) but also being willing to give potential managers and leaders the responsibilities that invariably come with on-the-job experience.

\section{Research Methodology Literature base}

This study used both a literature review and quantitative empirical analyses. The literature employed the previously identified management and leadership competencies (and their respective measuring criteria) (see Shaikh, Bisschoff and Botha, 2017) to develop a measuring model based on the methodology employed by other studies that succeeded to do so (Bisschoff and Moolla, 2015; Naidoo, 2011; Imandin, 2014; and others). Here Imandin, Bisschoff and Botha (2015) developed seven steps to 
construct a model to measure employee engagement constructs successfully. These steps served as a guideline to develop the model to measure management and leadership competencies. Following the development of the model, this study then proceeds to measure the management and leadership competencies of business school educated managers.

\section{Data collection}

All executive MBA students of two selected private business schools served as the population. These schools are geographically servicing all areas of South Africa. The students attend study schools in Durban and Johannesburg. The study school held in June 2017 was used to collect the data in the classrooms. The students attending the classes were requested to complete the questionnaires. Participation was voluntary and anonymous. Trained research assistants, mostly lecturers of the business schools, distributed, assisted and collected the questionnaires. The lecturers were specifically used to collect the data because they have, in addition to being well briefed about the research project, good knowledge and understanding of academic research. A total of 385 questionnaires were distributed of which 362 completed and usable questionnaires were collected. Two questionnaires were unaccounted for a while 21 were incomplete. These questionnaires were discarded because they could not be used. This resulted in an effective $94.0 \%$ response rate. The data was captured by the Statistical Consultation Services of the North-West University and analysed with the IBM Social Package for Social Sciences Version 24 (SPSS, 2017).

\section{Methodology to development of the model}

The model to measure management and leadership competencies was developed through a set of seven steps proven to be successful and useful. These steps (as formulated by Imandin et al., 2015) are:

Step 1: A literature review on management and leadership competencies measurement

Step 2: Purification of competencies

Step 3: Questionnaire development

Step 4: Validity and data collection

Step 5: Validate measuring criteria per competency

Step 6: Reliability

Step 7: Refined model presentation

\section{Results}

A model to measure management and leadership competencies

After performing Steps 1 and 2 in model development, the final model has a total of eleven management and leadership competencies. Measuring criteria have also been identified for each of the competencies. The criteria and competencies are measurable; this resulted in the successful construction of the questionnaire (Step 3).

Steps 4, 5 and 6 require statistical proof. Here validating the measuring criteria of the respective management and leadership competencies, the sample adequacy, variance explained, and reliability requires calculation. Additionally, the analysis must confirm that the measuring criteria for each competency actually do measure that specific competency. Exploratory factor analysis is used to determine if these criteria all load onto the respective competency. This means that if the factor analysis extracts only one factor per competency, it implies that the relevant criteria measure one construct only; this is then the specific management and leadership competency (Field, 2009). This methodology was successfully applied in similar research settings by numerous researchers such as Basson (2014), Salim (2011), Bisschoff and Moolla (2015), Fields and Bisschoff (2014) and others. These authors also indicated that in the case where two factors are extracted, it means that the competency actually consists of two subcompetencies, hence not measuring one management and leadership competency. Alternatively, a criterion could also load poorly (factor loading $\leq 0.40$ ) which will diminish its importance in the measurement of the competency. Low loadings lead to the omission of such a criterion from further analysis. The results of the sample adequacy, sphericity and reliability analyses appear in Table 1 while Table 2 shows the factor analysis and factor loadings per competency. 
Table 1: Management and leadership competencies suitability statistics

\begin{tabular}{|l|l|l|l|l|}
\hline Competency & $\begin{array}{l}\text { Sample } \\
\text { adequacy }\end{array}$ & Sphericity & Reliability & $\begin{array}{l}\text { Variance } \\
\text { explained }\end{array}$ \\
\hline Personal Value System & 0.676 & 0.00 & 0.600 & $46.0 \%$ \\
\hline Career Awareness & 0.778 & 0.00 & 0.772 & $59.5 \%$ \\
\hline Ethical and External Influences & 0.718 & 0.00 & 0.694 & $52.5 \%$ \\
\hline Leading Change & 0.766 & 0.00 & 0.717 & $49.8 \%$ \\
\hline Cultural Sensitivity & 0.738 & 0.00 & 0.640 & $65.9 \%$ \\
\hline Team Building & 0.734 & 0.00 & 0.787 & $62.1 \%$ \\
\hline Strategic Leadership & 0.755 & 0.00 & 0.739 & $58.3 \%$ \\
\hline Conflict Management & 0.681 & 0.00 & 0.755 & $67.4 \%$ \\
\hline Communication Skills & 0.841 & 0.00 & 0.861 & $58.3 \%$ \\
\hline Global Leadership Mindset & 0.500 & 0.00 & 0.845 & $86.7 \%$ \\
\hline Emotional Intelligence & 0.794 & 0.00 & 0.856 & $70.2 \%$ \\
\hline
\end{tabular}

*Unreliable $(0.57<a) ;{ }^{* *}$ Marginal reliability $(0.57 \leq a<0.70) ;{ }^{* * *}(a \geq 0.70)$ Reliable

The results show that all the competencies show satisfactory sample adequacy except the competency Global leadership mindset. Here the sample adequacy is marginal. A KMO value of 0.50 is still acceptable, although higher values exceeding 0.60 are preferable (Field, 2009). This favourable result indicates that each of the competencies are indeed measured by their respective criteria. Further, these results indicate that all but two competencies have satisfactory reliability coefficients $(a \geq 0.70)$. These two competencies (External and ethical influences and Personal value system) exceeded the lower reliability coefficient set by Cortina (1993) ( $a \geq 0.57)$. How well each competence is measured by the criteria is indicated by the variance explained; this should ideally exceed $60 \%$, although if $50 \%$ variance is explained, it is also regarded as acceptable. Here the competency Personal Value System shows $46 \%$ variance which is below the required $50 \%$. Leading change is acceptable with its variance at $49.8 \%$. This is marginally lower than $50 \%$, but the competency shows excellent reliability. The competency is thus retained for measurement based on the supportive reliability coefficient. No simplification or reduction of measuring criteria could be done as the theoretical model proved to be statistically valid, and all the criteria do measure the competencies as indicated by the literature study.

The results then mean, in practice, that the model is suitable to measure the management and leadership competencies. It also means that the competencies and their respective criteria are deemed fit to perform this measurement.

From the analysis in Tables 1 and 2, the theoretical model could be statistically validated as a tool to measure management and leadership competencies. From Table 2, the model's competencies do not break up into sub-competencies. This result substantiates that a thorough literature basis for the model was used.

Step 7 requires the presentation of the model. The model to measure management and leadership competencies is shown in Figure 1. The relevant competencies, its reliability and its variance explained are also indicated in the model. 
Table 2: $\quad$ Factor analysis of individual managerial competence

\begin{tabular}{|c|c|c|c|c|c|}
\hline $\begin{array}{c}\text { Personal Value } \\
\text { System }\end{array}$ & $\begin{array}{c}\text { Factor } \\
\text { loadings }\end{array}$ & Career Awareness & Factor loadings & $\begin{array}{c}\text { Ethical and } \\
\text { External Influences }\end{array}$ & Factor loadings \\
\hline PVS2 & 0.776 & CAW2 & 0.791 & EEI3 & 0.744 \\
\hline PVS4 & 0.671 & CAW3 & 0.786 & EEI4 & 0.733 \\
\hline PVS1 & 0.649 & CAW4 & 0.760 & EEI1 & 0.713 \\
\hline PVS3 & 0.605 & CAW1 & 0.749 & EEI2 & 0.706 \\
\hline Leading Change & $\begin{array}{c}\text { Factor } \\
\text { loadings }\end{array}$ & $\begin{array}{c}\text { Communication } \\
\text { Skills }\end{array}$ & Factor loadings & $\begin{array}{c}\text { Strategic } \\
\text { Leadership }\end{array}$ & Factor loadings \\
\hline LEC $2 \mathrm{~A}$ & 0.803 & $\cos 4$ & 0.819 & STL3 & 0.824 \\
\hline LEC1 & 0.789 & $\cos 2$ & 0.788 & STL2 & 0.816 \\
\hline LEC3 & 0.778 & Cos5 & 0.782 & STL1 & 0.803 \\
\hline LEC2 & 0.563 & $\cos 1$ & 0.758 & STL4 & 0.587 \\
\hline LEC4 & 0.548 & $\cos 3$ & 0.662 & & \\
\hline $\begin{array}{c}\text { Conflict } \\
\text { Management }\end{array}$ & $\begin{array}{c}\text { Factor } \\
\text { loadings }\end{array}$ & Team Building & Factor loadings & $\begin{array}{c}\text { Emotional } \\
\text { Intelligence }\end{array}$ & Factor loadings \\
\hline COM2 & 0.856 & TEB3 & 0.875 & EMI3 & 0.878 \\
\hline COM1 & 0.805 & TEB4 & 0.829 & EMI4 & 0.863 \\
\hline \multirow[t]{2}{*}{$\mathrm{COM} 3$} & 0.800 & TEB1 & 0.733 & EMI2 & 0.816 \\
\hline & & TEB2 & 0.703 & EMI1 & 0.791 \\
\hline Cultural Sensitivity & $\begin{array}{c}\text { Factor } \\
\text { loadings }\end{array}$ & $\begin{array}{c}\text { Global Leadership } \\
\text { Mindset }\end{array}$ & Factor loadings & & \\
\hline CUS2 & 0.863 & GLM2 & 0.931 & & \\
\hline CUS1 & 0.854 & GLM1 & 0.931 & & \\
\hline CUS3 & 0.709 & & & & \\
\hline
\end{tabular}

The model to measure management and leadership competencies is shown in Figure 2.

Figure 2: $\quad$ A model to measure management and leadership competencies

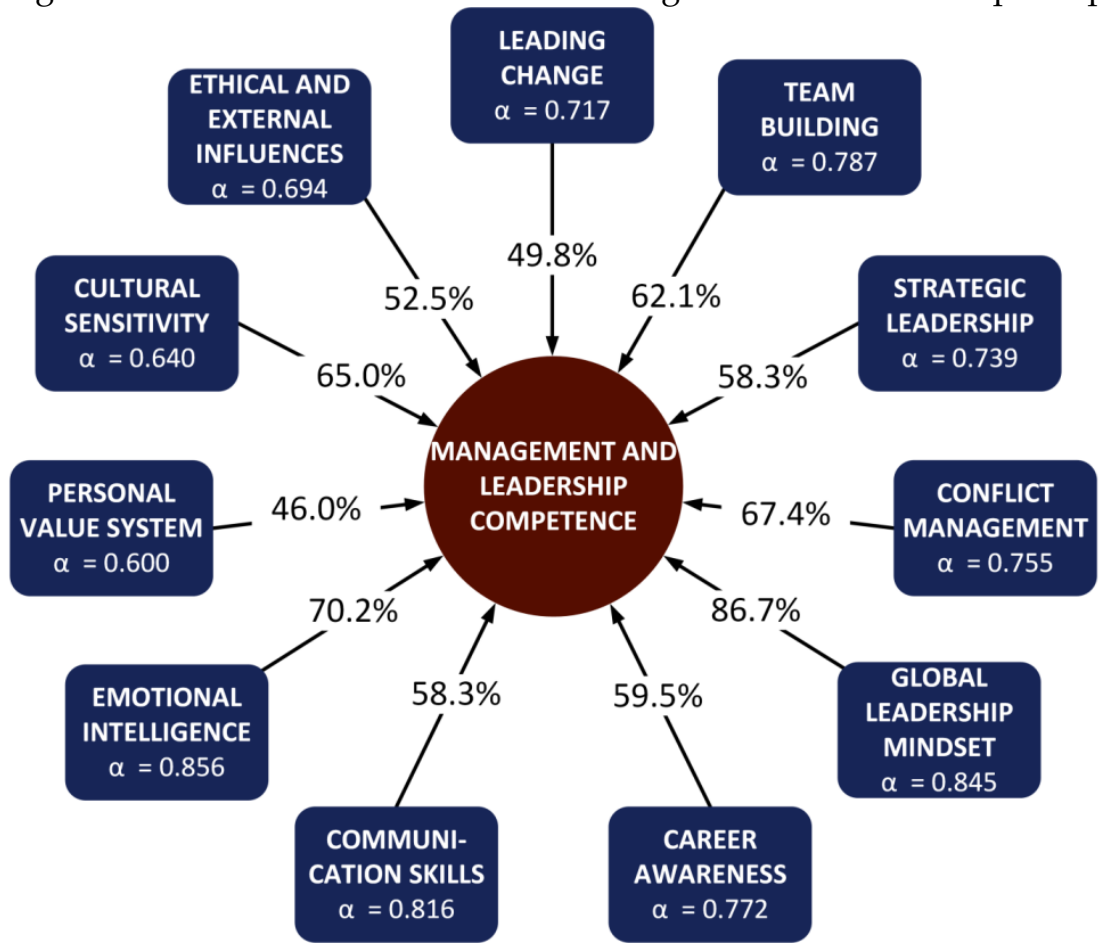

Source: Compiled from empirical results

Figure 2 shows the competencies that measure management and leadership competencies; its variance explained and the reliability of each competency. The competency Global Leadership Mindset explains the most variance $(86.7 \%)$ while also showing a high reliability coefficient (0.845). Inversely, 
Personal value system is the competency that explains the least variance $(46.0 \%)$ and has the lowest reliability coefficient of 0.600 . This, however, does exceed the minimum reliability coefficient of 0.57 set by the guidelines by the seminal reliability study of Cortina (1993).

The demographic profile of respondents

The demographic profile of the respondents is shown in Table 3 below.

Table 3: Demographic profile

\begin{tabular}{|c|c|c|c|}
\hline Demographic variable & Percentage & Demographic variable & Percentage \\
\hline $\begin{array}{l}\text { Gender } \\
\text { Male } \\
\text { Female }\end{array}$ & $\begin{array}{l}50.4 \\
49.6 \\
\end{array}$ & $\begin{array}{l}\text { Do you manage people } \\
\text { Yes } \\
\text { No }\end{array}$ & $\begin{array}{l}71.4 \\
28.6\end{array}$ \\
\hline $\begin{array}{l}\text { Age } \\
\text { Less than } 26 \text { years } \\
26-30 \text { years } \\
31-35 \text { years } \\
36-40 \text { years } \\
41-45 \text { years } \\
\text { More than } 45 \text { years }\end{array}$ & $\begin{array}{l}5.4 \\
19.1 \\
27.0 \\
19.4 \\
18.1 \\
11.1 \\
\end{array}$ & $\begin{array}{l}\text { Education } \\
\text { Diploma } \\
\text { Degree } \\
\text { Masters } \\
\text { MBA } \\
\text { Doctorate } \\
\text { Others } \\
\end{array}$ & $\begin{array}{l}17.4 \\
39.1 \\
29.6 \\
7.6 \\
4.9 \\
1.1 \\
\end{array}$ \\
\hline $\begin{array}{l}\text { Home language } \\
\text { English } \\
\text { Afrikaans } \\
\text { isiZulu } \\
\text { Tswana } \\
\text { Sesotho } \\
\text { Other }\end{array}$ & $\begin{array}{l}43.5 \\
3.0 \\
26.7 \\
3.0 \\
6.6 \\
17.1\end{array}$ & $\begin{array}{l}\text { How long have you been managing } \\
\text { people? } \\
\text { Up to a year } \\
\text { Between } 1 \text { and } 2 \text { years } \\
\text { More than } 2 \text { and up to } 3 \text { years } \\
\text { More than } 3 \text { and up to } 5 \text { years } \\
\text { More than } 5 \text { and up to } 10 \text { years } \\
\text { More than } 10 \text { years }\end{array}$ & $\begin{array}{l}12.5 \\
11.5 \\
9.9 \\
16.8 \\
\\
25.7 \\
23.7 \\
\end{array}$ \\
\hline $\begin{array}{l}\text { Working experience } \\
\text { Less than } 1 \text { year } \\
1 \text { to } 2 \text { years } \\
\text { More than } 2 \text { and up to } 3 \text { years } \\
\text { More than } 3 \text { and up to } 5 \text { years } \\
\text { More than } 5 \text { and up to } 10 \text { years } \\
\text { More than } 10 \text { years }\end{array}$ & $\begin{array}{l}1.1 \\
3.5 \\
5.1 \\
12.5 \\
25.5 \\
52.3\end{array}$ & $\begin{array}{l}\text { The biggest team you ever managed } \\
\text { comprised how many people? } \\
\text { Up to } 5 \\
\text { Between } 6 \text { and } 10 \\
\text { Between } 11 \text { and } 15 \\
\text { Between } 16 \text { and } 25 \\
\text { Between } 26 \text { and } 35 \\
\text { More than } 35\end{array}$ & $\begin{array}{l}19.7 \\
25.2 \\
14.8 \\
12.9 \\
6.8 \\
20.6\end{array}$ \\
\hline
\end{tabular}

Measuring the management and leadership competencies

The data is captured on a structured 5-point Likert scale questionnaire, which was designed to measure the business school educated managers' management and leadership competencies. The scale to do so range from 1 (which represented the category "Totally disagree") to 5 (which indicated a response in the "Totally agree" category).

Inferential statistics were used, and the mean values and standard deviations were calculated to indicate the agreement, or not, to the importance of the required managerial and leadership competencies and their respective measuring criteria. The mean values were interpreted by using two indicators. Firstly, as an initial indicator, the mid-point indicated if a competency is important (thus scoring higher than the midpoint of three), or whether it is not (then scoring below the midpoint). This interpretation was developed by Fullerton (1993) and successfully applied globally in various management studies (see Fullerton, 1993; Fullerton and Neale 2008a; 2008b; Bisschoff, 2017; Craven, 2010; Fullerton, Bisschoff \& Fields, 2017). Secondly, the mean value was interpreted to provide more information on the required competency by providing a relative measure of importance or unimportance of a criterion or a competency. Here various managerial studies (such as; Thekiso, 2011; Salim 2011; Basson, 2014; Liebenberg 2016) successfully applied the guidelines to interpret the mean scores using the guidelines originally applied by Bisschoff and Hough (1995) where: 
Scores of 1.5 and lower indicate that the management and leadership competency is not very important; Scores above 1.5 but below 3.5 an indicate important management and leadership competency; Scores of 3.5 and higher indicate a very important management and leadership competency; and Standard deviations more than one indicate that the respondents do differ from one another, while deviations higher than 1.5 shows that they differ a lot from one another on the importance of the criterion.

Almost all the competencies show high levels of importance (scoring a mean of higher than 3 or even 3.5). However, the mean values of the competency Personal value system are an exception. Three of the criteria scored below 3 . This indicated that respondents do not regard applying one's own beliefs and values, leadership traits are built on character, and a solid leadership character is indispensable as important issues. These criteria all also have high standard deviations showing that all respondents are not in agreement on this competency. Interesting though is that the respondents do believe that ethics play an important role in a leader's personal value system. The competency thus has a low mean score of 2.58 indicating a low level of importance. The other competency that shows marginal importance is Career awareness with a mean (3.18) that is below the higher importance level of 3.5 but well above the lower margin of 3. The mean values of the competencies are shown in Figure 4 below.

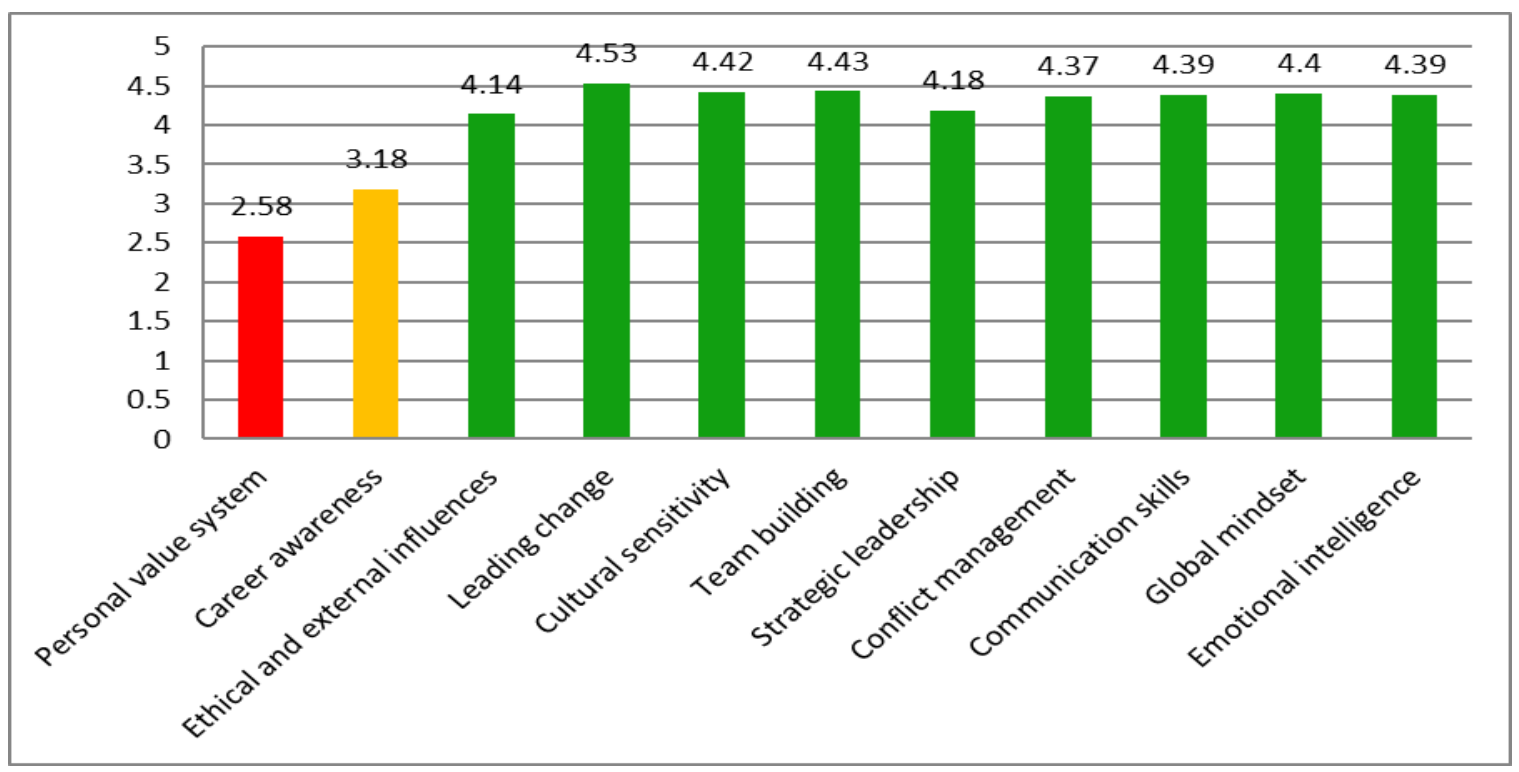

Figure 4: $\quad$ Mean values of competencies

Source: Compiled from empirical analysis

Figure 4 shows that a Personal value system and Career awareness rank the lowest among the respondents. The rest of the competencies are well presented and score above 3.5.

\section{Correlational analysis}

Pearson's correlation coefficient was used to determine if the demographic variables correlate significantly with any of the competencies. The analysis showed that although some significant correlations do exist, these correlations are very low ( $\mathrm{p} \leq 0.05 ; \mathrm{r} \leq 0.2)$. This means that, in practice, the demographic variables do not strongly influence on any of the competencies (Field, 2009). However, the correlations between the competencies were all significant and high $(\mathrm{p} \leq 0.05 ; \mathrm{r} \geq 0.5)$. This means that the improvement in any competency has a large positive influence on all the other competencies; in practice, it implies that management and leadership competence levels achieve development synergy and as one skill improves, so do the others. This supports the theory consulted to identify competencies and indicates that all the competencies identified from the theoretical study are statistically inter-related and do indeed measure only one construct; that is management and leadership competence. 


\section{Discussion}

The study used a scientifically-researched process proved to be successful and useful by some social science studies to successfully construct a model to measure management and leadership competencies. The methodology identified 11 competencies which are measured by 42 criteria. Like some social studies the methodology proved successful in theoretical model development.

Following the identification of relevant management and leadership competencies from the literature, the relevance and importance of the competencies was confirmed statistically and proceeded to compile a final list of management and leadership competencies to use in measuring management and leadership competencies. The results showed that a Personal value system and Career awareness scored the lowest; in practice, this means that these competencies are not well developed among the managerrespondents. These are also areas of development that organisations should develop to provide their managers with an opportunity to gain better management and leadership competencies. Regarding correlations between the competencies, the Pearson correlations identified significant low, correlations between the demographic variables and the competencies, and also significantly high correlations between the competencies. In practice, this means that no demographic variables influence any of the competencies, but that the different competencies, by the literature, measures one core construct, namely that of management and leadership.

\section{Limitations and Possible Future Research Areas}

The developed model to measure management and leadership competencies offer two limitations. First, the model cannot be operationalised at present to a larger population of managers as the findings result from university-educated managers. Many managers and leaders developed their managerial competencies through experience. This study did not compensate for this group. As a result, this limitation offers a possible area for further research, namely, to test and measure the model among this respondent group. Second, the respondents in the model are diverse in ethnic and cultural demographics; however, the study did not specifically classify each demographic variable and compare the different groups with one another. This limitation offers another future research possibility namely to analyse if these demographic variables do make a difference. Various examples exist; male versus female competencies, cultural or ethic competency differences and if age or type of experience plays a role in management and leadership competencies. Furthermore, are these differences significant or not?

\section{References}

Achadinha, N., Benedict, E., Boshoff, S., Flotman, A.P., Taljaard, J., Van der Walt, A., Van Noordwyk, A. \& Vermeulen, W. (2015). General management. Pretoria: Van Schaik.

Alvesson, M. \& Svenningson, S. (2003). Managers doing leadership: the extra-ordinarization of the mundane. Human Relations, 56(12):1435-1459.

Analoui, F. \& Hosseini, M.H. (2001). Management education and increased managerial effectiveness: The case of business managers in Iran. Journal of Management Development, 20(9):785-794.

Anderson, E. (2012). Are leaders born or made? https://www.forbes.com/sites/erikaandersen/2012/11/21/areleaders-born-or-made/\#f4a82fe48d56 Date of access: 10 October 2017.

Aruda, W. (2016). 9 Differences between being a leader and a manager.

https://www.forbes.com/sites/williamarruda/2016/11/15/9-differences-between-being-a-leader-and-amanager/\#7cff01c74609 Date of access: 10 October 2017.

Ayers, K. (2015). A gift of inspiration. Five leadership skills that increase engagement.

http://www.agiftofinspiration.com.au/stories/ leadership/Five.shtml Date of access: 30 March 2015.

Bagraim, J., Cunningham, P., Potgieter, T. \& Viedge, C. (2016). Organisational behaviour. $4^{\text {th }}$ ed. Pretoria: Van Schaik.

Basson, S. (2014). Measuring the effect of loyalty programmes on a leading pet food brand. (Dissertation - MBA). Potchefstroom: North-West University.

Bedeian, A.G. \& Hunt, J.G. (2006). Academic amnesia and vestigial assumptions of our forefathers. Leadership Quarterly, 17(2):190-205.

Biro, M. (2014). Management and leadership competence is a leadership commitment.

http://www.forbes.com/sites/meghanbiro/2014/03/30/employee-engagement-is-a-leadership-commitment/ Date of access: 30 March 2015.

Bisschoff, C.A \& Hough, J. (1995). Retaining the competitive edge in SA organised agriculture through customer service management. First Asian annual management conference, Academy of management, Penang, Malaysia, 6-7 December.

www.jbrmr.com A Journal of the Academy of Business and Retail Management (ABRM) 
Bisschoff, C.A. \& Moolla, A.I. (2015). A simplified model to measure brand loyalty of fast-moving consumer goods. Journal of Humanities, 55(4):652-664.

Bisschoff, C.A. (2017). A longitudinal view of the attitudes on business ethics of South African managers: trends from 2007 to 2016. Journal of Humanities, In press.

Bolden, R. (2007). Trends and perspectives in management and leadership development. Business Leadership Review, $4(2): 1-13$

Boyatzis, R.E. \& Case, A.R. (1989). The impact of an MBA programme on managerial abilities. Journal of Management Development, 8(5):66-77.

Boyatzis, R.E. \& Ratti, F. (2009). Emotional, social and cognitive intelligence competencies distinguishing effective Italian managers and leaders in a private company and cooperatives. Journal of Management Development, 28(9):821-838.

Brocklehurst, M., Grey, C. \& Sturdy, A. (2009). Management: the work that dares not speak its name. Management Learning, 41(1):7-19.

Burns, J.M. (1978). Leadership. New York, NY: Harper and Row.

Buttigieg, S.C. \& West, M.A. (2013). Senior management leadership, social support, job design and stressor-to-strain relationships in hospital practice. Journal of Health Organisation and Management, 27(2):171-192.

Camuffo, A., Gerli, F., Borgo, S. \& Somià, T. (2009). The effects of management education on careers and compensation: A competency-based study of an Italian MBA programme. Journal of Management Development, 28(9):839-858.

Cornellissen, J (2017). Corporate Communication: A Guide to Theory and Practice. $5^{\text {th }}$ ed. London: Sage.

Cortina, J.M. (1993). What is coefficient Alpha? An examination of theory and applications. Journal of Applied Psychology, 78(1):98-104.

Craven, P. (2010). Ethical perceptions: management versus production at a large multinational seed company. (Dissertation - MBA). Potchefstroom: North-West University.

De Wit, B. (2017). Strategy: an international perspective. $6^{\text {th }}$ ed. Hampshire: Cengage.

Dissanayake, N. (2016). Are good managers born or made? http://www.sundaytimes.lk/141005/business-times/aregood-managers-born-or-made-120309.html Date of access: 10 September 2017.

Edunote. (2017). Why leaders are born but managers are made. https://iedunote.com/leaders-are-born-managersare-made Date of access: 10 September 2017.

Edwards, G., Schedlitzki, D., Turnbull, S. \& Gill, R. (2015). Exploring power assumptions in the leadership and management debate. Leadership \& Organisation Development Journal, 36(3):328-343.

Edwards, G.P., Winter, P.K. \& Bailey, J. (2002). Leadership in management. Nature or nurture? Turning to the military in the leadership debate. Strategic Direction, 18(8):10-12.

Field, A.P. (2009). Discovering statistics using SPSS. 3rd ed. London: Sage.

Fields, Z. \& Bisschoff, C.A. 2013a. A model to measure creativity in young adults, Journal of Social Sciences, 37(1):55-67.

Fullerton, S. \& Bisschoff, C.A. (2013). Ethical predisposition of business students: using the results from 12 countries to compare attitudes on six continents. 7th International Business Conference, Mahe, Seychelles.

Fullerton, S. (1993). The ethical predisposition of our next generation of business and community leaders. In Roberta Good (ed.), Proceedings of the Atlantic Marketing Association, (March), (pp. 317-323).

Fullerton, S. and Neale, L. (2008a). Comparing the ethical predisposition of university students in five Englishspeaking countries: An examination of 14 questionable business practices. In W. Riecken and D. Shepherd (eds.), Proceedings of the Association of Marketing Theory and Practice, 17, 144-152.

Fullerton, S. and Neale, L. (2008b). Comparing the ethical predisposition of university students in five Englishspeaking countries: An examination of 14 questionable consumer actions. In W. Kehoe and L. Whitten, (eds.), Proceedings of the Society of Marketing Advances, 57, 193-194.

Fullerton, S., Bisschoff, C. A. and Fields, Z. (2017). A look at the ethical predispositioning of future South African Business leaders regarding potential misbehavior on both sides of the buyer-seller dyad. In J. Fowler (ed.), Proceedings Society for Marketing Advances, 3-7 November 2017. Louisville, KY.

Ghoshal, S. (2005). Bad management theories are destroying good management practices. Academy of Management Learning and Education, 4(1):75-91.

Gill, R. (2006). Theory and practice of leadership. London: Sage.

Gleeson, B. (2016). Combining visionary leadership and great management achieves winning results. https://www.inc.com/brent-gleeson/the-fundamental-differences-between-leadership-andmanagement.html Date of access: 10 September 2017.

Grint, K. (2005). Problems, problems, problems: the social construction of leadership. Human Relations, 58(11):14671494.

Hoffman, R. (2016). Interview: Paypal and LinkedIn. Boston, MA: Harvard Business Review. 
Horan, L. (2013). 6 Tips for successfully measuring management and leadership competencies. http:/ / www.businessbee.com/resources/operations/6-tips-for-successfully-measuring-employeeengagement/ Date of access: 11 April 2015.

House, R.J. \& Aditya, R.N. (1997). The social science study of leadership: quo vadis?. Journal of Management, 23:409474.

Imandin, L. (2015). Developing a Conceptual Framework to Analyse Engagement and Disengagement in the Workplace. (Thesis - PhD). Potchefstroom: North-West University.

Imandin, L., Bisschoff, C.A. \& Botha, C.J. (2016). Confirmatory analysis of the model to measure employee engagement. Problems and Perspectives in Management, 14(2):93-103

Insala. (2015). How to engage employees. http://www.insala.com/how-to-engage-employees/ Date of access: 15 March 2015.

Kakabadse, A.P. \& Kakabadse, N. 1999. Essence of leadership. London: Thomson International.

Kent, T.W. (2005). Leading and managing: it takes two to tango. Management Decision, 43(7/8):1010-1017.

Kotter, J.P. (1990a). What leaders really do. Harvard Business Review, 68(3):103.

Kotter, J.P. (1990b). A force for change: How leadership differs from management. New York, NY: Free Press.

Lewis, R., Donaldson-Feilder, E. \& Tharani, T. (2012). Managing for sustainable management and leadership competencies: developing a behavioural framework. http://www.cipd.co.uk/binaries/managing-forsustainable-employee-engagement-developing-a-behavioural-framework_2012.pdf Date of access: 22 March 2015.

Lussier, R.N. \& Achua, C.F. (2013). Leadership: Theory, application, \& skill development. 6 ${ }^{\text {th }}$ ed. Mason, OH: SouthWestern.

McClelland, D.C. (1973). Testing for competence. American Psychologist, 28(1):1-14, January.

Mintzberg, H. (2004). Enough leadership. Harvard Business Review. November. https://hbr.org/2004/11/enoughleadership

Mintzberg, H. (2005). Managers, not MBAs: A hard look at the soft practice of managing and management development. San Francisco, CA. Berrett-Koehler.

Mintzberg, H. (2008). Mintzberg's 10 managerial roles.

http:/ / management.atwork-network.com/2008/04/15/mintzberg\%E2\%80\%99s-10-managerial-roles/ Date of access: 5 May 2017.

Mintzberg, H. (2009). Managing. San Francisco, CA: Berrett-Koehler.

MMG. (2013). Management Study Guide. Management and leadership competencies and Employee Retention. http://www.managementstudyguide.com/employee-engagement-employee-retention.htm Date of access: 5 May 2017.

Mullins, L.J. (2010). Management and organisational behaviour. 9th ed. London: Financial Times Prentice Hall.

Naidoo, K. (2011). Stress management and its impact on work performance of educators in public schools in KwaZulu-Natal. Potchefstroom: North-West University (Thesis - PhD).

Nanus, B. (1992). Visionary leadership: creating a compelling sense of direction for your organisation. San Francisco, CA: Jossey-Bass.

Nienaber, H. (2010). Conceptualisation of management and leadership. Management Decision, 48(5):661-675.

Northouse. P.G. (2016). Leadership: Theory and Practice. $7^{\text {th }}$ ed. Thousand Oaks, CA: Sage.

Pfeffer, J. \& Fong, C. (2004). The business school "Business": Some lessons from the U.S. experience. Working Paper No. 1855. https://www.gsb.stanford. edu/faculty-research/working-papers/business-school-business-somelessons-us-experience Date of access: 5 May 2017.

Robbins, S.P. \& Judge, T.A. (2012). Organisational behavior. 15th ed. New York, NY: Prentice Hall.

Rowlands. (2006). Rowlands International Survey Results on perceptions between managers and employees. http://www.rowlandsonline.com/images/result_survey_ri_01.pdf Date of access: 5 May 2017.

Salim, S.F. (2011). An assessment of brand loyalty of banking clients. (Thesis - PhD). Potchefstroom: North-West University.

Shaikh, A. (2013). Management competence measurement for business school educated managers. Durban: Management College of South Africa. (Dissertation - MBA).

Shuck, B. \& Reio, G. (2013). Management and leadership competencies and Well-being: A moderation model and implications for practice. Journal of leadership and Organisational Studies, 21(1):43-58.

Sinclair, A. (2007). Leadership for the disillusioned. Sydney: Allen \& Unwin.

Sinh, R. (2016). Competencies: descriptions, indicators and examples.

https://education.alberta.ca/media/3272998/competency-indicators-september-30-2016.pdf Date of access: 10 October 2017.

Smit, P., Botha, T. \& Vrba, M. (2016). Management principles. Cape Town: Juta. 
Thekiso, T.A. (2011). Management skills measurement of business school educated managers in the North West and Vaal triangle areas. (Thesis - PhD). Potchefstroom: North-West University.

Truxillo, D.M., Bauer, T.N., \& Erdogan, B. (2016). Psychology and work: Perspectives on industrial and organisational psychology. New York, NY: Routledge.

Tucker, R.C. (1968). The theory of charismatic leadership. Daedalus, 97(3):731-756.

Varela, O., Burke M. \& Norbet, M. (2013). The development of managerial skills in MBA programs: A reconsideration of learning goals and assessment procedures. Journal of Management Development, 32(4):435-452.

Walters, N. (2016). 17 of the biggest differences between managers and leaders.

http://www.businessinsider.com/biggest-differences-between-managers-and-leaders-2016-3 Date of access: 5 May 2017.

Yukl, G. \& Lepsinger, R. (2005). Why integrating the leadership and management roles are essential to organisational effectiveness? Organisational Dynamics, 34(4):361-375.

Zaleznik, A. (1977). Managers and leaders: Are they different? Harvard Business Review, 67-78. 